\title{
Pengaruh Penerapan Sistem Informasi Pemeliharaan Peralatan Dan Mesin Kantor Pada Efisiensi
}

\author{
Muhammad Amrin Lubis ${ }^{1}$, Isteti Murni ${ }^{2}$, MH. Arfansyah ${ }^{3}$ \\ ${ }^{1,2,3}$ STMIK Indonesia Padang \\ maloebis@gmail.com, istetimurni@gmail.com, mh.lathif@gmail.com
}

\begin{abstract}
ABSTRAK
Pemeliharaan peralatan dan mesin kantor merupakan kegiatan rutin Dinas Pendidikan Kabupaten Tanah Datar dalam usaha meningkatkan kemampuan kerja dan memperpanjang usia pakai peralatan dan mesin. Administrasi pencatatan data keadaan, pembiayaan, dan pelaporan masih dilakukan secara manual. Munculnya teknologi Sistem Informasi telah merubah manajemen pelayanan pemeliharaan. Banyak informasi pemeliharaan Peralatan dan Mesin Kantor yang tersedia pada Sistem Informasi ini diantarnya: riwayat pememeliharaan, rekam biaya pemeliharaan danpelacakan informasi yang relevan seperti penyebab masalah hal ini semua membantu manajemen menjadi efisien. Sistem Informasi Pemeliharaan dibangun denganVisual C Sharp dan menggunakan database MySQL. Pegawai yang terlatih mengoperasikan Sistem Informasi ini tentu dapat menggunakan semua fitur yang ada dengan demikian ketersediaan akan informasi pemeliharaan Peralatan dan Mesin Kantor dapat tersimpan dengan lengkap diantaranyariwayat pemeliharaan tentang: tanggal kejadian, kerusakan, spare spart yang diganti, lama waktu perawatan dan biaya yang ditimbulkan. Selain itu Sistem juga memberikan informasi frekuensi pemeliharaan peralatan dan mesin kantor. Ketersediaan informasi ini akan mengakibatkan efisiensi.
\end{abstract}

Keywords: pemeliharaan peralatan dan mesin, C\#, MySQL

\section{PENDAHULUAN}

Konsep pemeliharaan di bidang peralatan yang kompleks dikembangkan di USA yang cepat diadopsi oleh negara-negara Eropa dan Jepang. Konsep perawatan di Amerika memiliki arti penting dalam menciptakan sistem dukungan untuk fungsi peralatan industri. Fungsional pemeliharaan adalah salah satu metode yang paling sering digunakan dalam manajemen pemeliharaan untuk industri perusahaan(Cucu, 2009).

Tulisan ini berkaitan dengan topik penggunaan Sistem Informasi berfokus pada area pemeliharaan peralatan kantor dan mesin dan pentingnya untuk meningkatkan daya saing perusahaan. Pentingnya fungsional penggunaan Sistem Informasi dalam pemeliharaan peralatan kantor dan mesin pada Dinas Pendidikan Kabutapan Tanah Datar telah meningkat secara perlahanakhir-kahir ini. Alasan untuk ini adalah meningkatnya tekanan pada pengurangan biaya dan nilai tambah bagi pengelolaan manajemen dari instansi.

Munculnya teknologi baru telah berubah manajemen pelayanan pemeliharaan (Havlík, 2011). Penerapan Sistem Informasi pemeliharaan peralatan kantor dan mesin dalam pengumpulan data ke Instansi dan pemantauan operasi pemeliharaan dapat menghemat biaya tambahan untuk Instansi dan membuat peralatan bekerja lebih efektif. Parameter yang dapat mempengaruhi efektivitas ini adalah sebagai berikut: rata-rata waktu perbaikan, waktu antar kerusakan mesin, total waktu kegagalan. Parameter ini dapat memiliki pengaruh yang signifikan pada total waktu shutdown sementara garis produksi dari total waktu produksi ('downtime'). Ini memiliki efek langsung pada efisiensi perusahaan. Hasil parameter ini juga tergantung pada sistem pemantauan data, analisis dan pelaksanaan pengukuran terkait (Vyskocil, 2010). 
Tugas utama dari Bagian Umum Perlengkapan dalam Instansi adalah untuk memastikan bahwa peralatan danmesin beroperasi dengan benar dan efisien. Kewajiban lain yang harus dipenuhi adalah untuk memaksimalkan umur peralatan dan mesin untuk mengurangi kemungkinan kegagalan.

Pemeliharaan adalah segala usaha yang dilakukan terus menerus untuk mengecek kelayakan peralatan dan mesin kantor yang digunakan dalam operasional kegiatan seharihari di Dinas Pendidikan Kabupaten Tanah Datar.

Menurut Sudradjat (2011), pemeliharaan atau lebih dikenal dengan kata maintenance dapat didefinisikan sebagai suatu aktivitas yang diperlukan untuk menjaga dan mempertahankan kualitas pemeliharaan suatu fasilitas agar fasilitas tersebut tetap dapat berfungsi dengan baik dalam kondisi siap pakai.

Dalam manajemen pemeliharaan dilaksanakan kegiatan mengikuti ketentuan pabrik pembuat, data sejarah identifikasi dan diagnosa kerusakan peralatan/mesin. Kegiatan pemeliharaan yang dilaksanakan tersebut meliputi perawatan/pemeriksaan, perbaikan, penggantian dan pengujian yang bertujuan diantaranya untuk mempertahankan kemampuan kerja peralatan/ mesin dan menghilangkan atau mengurangi resiko kerusakan mendadak yang akan mengurangi kerugian secara ekonomis.

Sehubungan dengan pemaparan tersebut, berdasarkan observasi penulis di Dinas Pendidikan Kabupaten Tanah Datar menunjukkan bahwa pengelolaan dan pemeliharaan barang milik daerah khususnya barang-barang peralatan dan mesin perkantoran belum dilaksanakan secara optimal. Data Kondisi peralatan dan mesin kantor tidak tercatat dengan baik dan lengkap sehingga perbaikan tidak tepat sasaran dan tidak memperhatikan skala prioritas. Di samping itu belum adanya pengaturan jadwal pemeliharaan berdampak kurang baik terhadap kinerja peralatan dan mesin kantor. Untuk mengetahui kondisi peralatan dan mesin kantor, Pimpinan kantor datang langsung ke masing-masing pemegang peralatan kantor untuk mengetahui keadaan dan kebutuhan peralatan dan mesin kantor karena kurangnya dukungan data dan informasi dari penanggung jawab peralatan dan mesin. Di samping itu penyusunan anggaran pemeliharaan peralatan dan mesin kantor tidak didukung oleh data realisasi anggaran pemeliharaan.

Oleh karenanya kegiatan pengelolaan dan pemeliharaan peralatan dan mesin perkantoran perlu dilakukan dengan baik agar dapat memberikan layanan yang didasarkan legalitas administrasi, kegiatan pengeloaan dan pemeliharaan peralatan dan mesin yang baik bukan hanya sekedar mencatat keberadaan peralatan dan mesin namun bagaimana data peralatan dan mesin bisa disajikan dengan tidak membosankan, dimengerti dan penataannya dapat terlihat dengan baik serta harus memperhatikan penyederhanaan dalam membuat suatu sistem yang rumit atau pekerjaan yang sukar menjadi lebih mudah dan ringan.

Penggunaan Sistem Informasi ini bertujuan untuk membantu pegawai Bagian Umum Perlengkapan melakukan administrasi pemeliharaan mengidentifikasiperalatan dan mesin yang membutuhkan perawatan. Hal ini juga memberikan informasi yang tepat kepada manajemen tentang situasi saat ini di tempat kerja. Lainnya fungsi Sistem Informasi yang menginformasikan riwayat pemeliharaan, merekam biaya danpelacakan informasi yang relevan seperti penyebab masalah.

\section{KAJIAN LITERATUR \\ 1.1 Sistem Informasi}

Sistem informasi merupakan tatanan yang saling terkait antara unsur data software, hardware, sumber daya manusia dan kelembagaan serta peraturannya. Mengembangkan sistem informasi berarti mengembangkan seluruh unsur tersebut secara menyeluruh, tidak bisa dilakukan secara parsial atau sendiri-sendiri. Adapun menurut Tata Sutabri (2012) sistem informasi adalah suatu sistem di dalam suatu organisasi yang mempertemukan kebutuhan pengolahan transaksi harian yang mendukung fungsi operasi organisasi yang bersifat manajerial dengan kegiatan strategi dari suatu organisasi 
untuk dapat menyediakan laporan-laporan yang diperlukan oleh pihak luar tertentu

Sistem informasi pemeliharaan peralatan dan mesin kantor di Dinas Pendidikan Kabupaten Tanah Datar belum memadai dalam proses penunjang keputusan. Saat ini informasi kondisi dan riwayat pemeliharaan peralatan dan mesin kantorbelum tersedia lengkap dengan database. Hal ini mengakibatkan peralatan dan mesin kantor kurang aspek pemeliharaan secara profesional.

Untuk mendapatkan sistem informasi yang handal, Dinas Pendidikan Kabupaten Tanah Datar memerlukan suatu mekanisme yang bisa menghasilkan suatu informasi yang bernilai dan berkualitas yaitu melalui proses perancangan sistem informasi berbasis database yang menciptakan perpaduan antara sumber daya manusia dan aplikasi teknologi informasi untuk memilih, menyimpan, dan mengolah data menjadi informasi dan mengambil kembali data dalam rangka mendukung proses pengambilan keputusan.

\subsection{Pemeliharaan}

Menurut Sudradjat (2011) menjelaskan bahwa pemeliharaan atau yang lebih dikenal dengan kata maintenance dapat didefinisikan sebagai suatu aktivitas yang diperlukan untuk menjaga atau mempertahankan kualitas pemeliharaan suatu fasilitas dan sarana prasarana agar dapat berfungsi dengan baik dalam kondisi yang siap pakai.

Berdasarkan definisi tersebut, maka terdapat beberapa alasan pentingnya melakukan pekerjaan pemeliharaan, antara lain Sudradjat (2011):

1. Agar fasilitas dapat siap dipakai pada saat yang diperlukan.

2. Seiring dengan waktu, tentunya kondisi dari suatu fasilitas yang mengalami pemakaian, kemampuan kinerjanya lambat laun akan menurun karena tanpa pemeliharaan semua fasilitas tersebut akan melemah secara bertahap tapi pasti, sehingga tidak lagi mempunyai kemampuan kerja baik secara teknis maupun ekonomis.

3. Diharapkan akan dapat memperpanjang umur pakai dari fasilitas tersebut.
Di dalam perkembangannya, evolusi perawatan terjadi melalui beberapa tahapan, yaitu sebagai berikut Sudradjat (2011):

1. Pemeliharaan tidaklah dikenal sebagai suatu keilmuan tertentu.

2. Pemeliharaan dianggap sebagai spesialisasi tersendiri.

3. Mulai memperhatikan pemeliharaan pencegahan.

4. Mulai diperkenalkan aspek-aspek manajerial.

5. Peran pemeliharaan masuk kedalam proses desain.

6. Pemeliharaan mulai menggunakan suatu perencanaan diseluruh operasi kegiatan pemeliharaan, dan data-data kejadian yang berhubungan dengan pekerjaan pemeliharaan dimasa lalu yang dipakai sebagai masukan.

Kegiatan pemeliharaan peralatan dan mesin, dapat dilihat pada gambar 2.1.

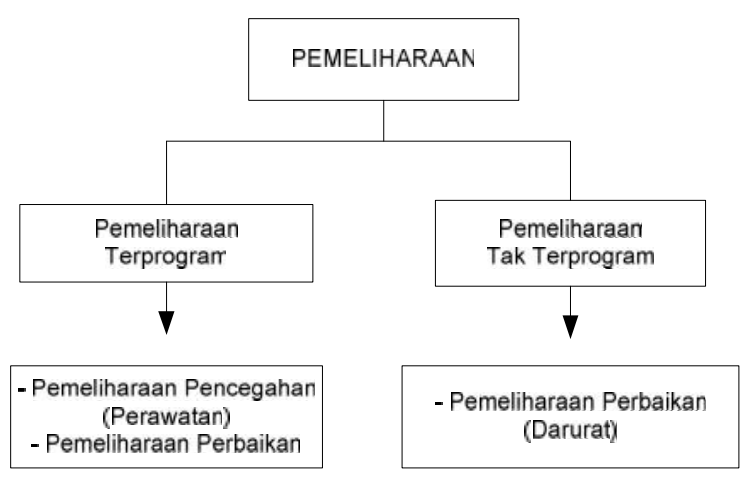

\section{Gambar 1.1. Sistematika Kegiatan Pemeliharaan}

\section{Pemeliharaan Terprogram}

Suatu kegiatan pemeliharaan yang diprogramkan dan merupakan salah satu kegiatan institusi/perusahaan yang dilakukan dengan pemikiran berorientasi ke masa depan, pengendalian dan pendataan sesuai dengan rencana yang telah ditetapkan sebelumnya. Termasuk didalamnya adalah:

a. Pemeliharaan pencegahan (perawatan)

Suatu kegiatan pemeliharaan yang dilaksanakan secara terencana dan periodik dalam bentuk penjadwalan (time schedule), tujuannya untuk mengurangi kemungkinan kerusakan, gangguan dan menjaga fasilitas 
dalam kondisi standar. Kegiatan pencegahan ini ada yang harus dilakukan harian seperti mencatat suhu mesin-mesin yang berputar, kegiatan mingguan seperti pemantauan tereminasi sambungan kabel pada peralatan listrik, kegiatan bulanan seperti mengganti mengganti minyak trafo atau mesin-mesin yang berputar serta kegiatan pencegahan tahunan seperti diantaranya melakukan pengecatan pada peralatan yang ada.

b. Pemeliharaan perbaikan

Suatu kegiatan pemeliharaan membawa fasilitas ke kondisi standar semula melalui perbaikan dari keadaan rusak sebelumnya. Kegiatan ini dapat dilakukan dalam pemeliharaan terprogram maupun pemeliharaan tak terprogram. Contoh kegiatan pemeliharaan perbaikan terprogram adalah kegiatan minor/mayor maintenance, yaitu kegiatan perbaikan yang bersifat kecil/besar namun hal ini sesuai dengan rekomendasi pabrik pembuat yang tercantum dalam manual instruction (petunjuk pabrik) untuk operasional mesin tersebut.

\section{Pemeliharaan tak terprogram}

Suatu kegiatan pemeliharaan akibat terjadinya kerusakan diluar perencanaan atau di luar dugaan, dan tidak termasuk dalam anggaran biaya. Yang termasuk dalam pemeliharaan tak terprogram umumnya adalah pemeliharaan darurat, seperti kerusakan mesin yang tiba-tiba pada saat kegiatan produksi berlangsung, maka mesin yang rusak tersebut harus segera diperbaiki untuk menghindari kerugiaan yang lebih besar karena berhentinya produksi.

Dalam keberhasilan pelaksanaan pemeliharaan diukur berdasarkan sedikitnya frekuensi dan lama waktu time down (fasilitas tidak berfungsi). Jadi down time peralatan karena kerusakan harus dihindarkan sedapat mungkin, melalui pemeliharaan perawatan (preventive) yang terprogram.

Ada beberapa macam pemeliharaan yang sering dilakukan oleh perusahaan dalam rangka melakukan perawatan mesin-mesin yang dimilikinya, antara lain:

a. Sistem pemeliharaan sesudah rusak (breakdown maintenance)

Tujuan pemakaian metode ini adalah untuk mendapatkan penghematan waktu dan biaya dan perbaikan dilakukan pada keadaan yang benar-benar perlu. Pada pemeliharaan sistim ini pekerja-pekerja pemeliharaan hanya akan bekerja setelah terjadi kerusakan pada mesin atau peralatan. Jika kita memakai sistim ini kerusakan mesin atau equipment akan terjadi berkali-kali dan frekuensi kerusakannya hampir sama saja setiap tahunnya. Artinya beberapa mesin atau equipment pada pabrik tersebut ada yang sering diperbaiki. Pada pabrik yang beroperasi secara terus menerus, dianjurkan untuk menyediakan cadangan mesin (stand by machine) bagi mesin-mesin yang vital. Sebagai tambahan, sistim ini untuk pembongkaran mesin-mesin pabrik tahunan tidak dipakai karena pada saat dilakukannya penyetelan dan perbaikan mesin, unit-unit mesin cadanganlah yangdipakai.

\section{b. Pemeliharaan Rutin (preventive maintenance) \\ Tipe pemeriksaan dan perbaikan preventive ini dibuat dengan} mempertimbangkan ketersediaan tenaga kerja, suku cadang, bahan untuk perbaikan dan faktor-faktor lainnya. Biaya perbaikan dan lamanya mesin/peralatan tidak beroperasi dapat diminimalkan dibandingkan dengan perbaikan mesin yang sama tetapi dilakukan setelah mesin itu rusak total. Sistim pemeliharaan mesin meliputi rencana inspeksi dan perbaikan secara periodik. Biaya pembuatan atau modal awal dapat dikurangi bila bagian pemeliharaan dapat memberikan informasi-informasi yang baik tentang masalah-masalah servis mesin/peralatan, pemasangan unit-unit cadangan dapat dibuat optimal. Selanjutnya dilakukan standarisasi jenis mesin dan suplier dan juga meningkatkan mutu barang tanpa menambah biaya hingga modal dapat dihemat dan juga biaya-biaya pemeliharaan selanjutnya.

\section{Sistem Pemeliharaan Ulang (corrective maintenance)}

Hal yang dilakukan dalam kegiatan pemeliharaan ulang umumnya terjadi pada peralatan atau mesin yang telah lama beroperasi, misalnya setelah beberapa tahun pemeliharaan rutin dilaksanakan di pabrik, dari data inspeksi yang telah dilakukan akan 
diketahui umur serta biaya dari masing-masing peralatan, kemudian dapat ditentukan prioritas unit yang harus segera diperbaiki. Ini akan menjadikan prosedur perbaikan yang baik untuk dapat meminimalkan waktu yang dipakai untuk pekerjaan pemeliharaan rutin. Umumnya jika proses pemeliharaan ulang telah berjalan baik, maka tidak diperlukan mesin atau peralatan cadangan karena kondisi masing-masing mesin/peralatan sudah lebih terjamin.

\section{Sistem Pemeliharaan Produktif}

Dari beberapa sistem pemeliharaan yang telah diuraikan di atas, dapat disimpulkan bahwa makin tinggi efisiensi makin tinggi pula keuntungan yang akan diperoleh, maka bila efisiensi yang tinggi tersebut belum memberi keuntungan yang diinginkan, maka perlu dipikirkan konsep baru yang lain. Dewasa ini pola pemeliharaan prediktif dianggap lebih efektif dan efisien jika jam operasi pada peralatan tersebut masih dalam petunjuk pabrikan, jika jam operasi sudah terpenuhi maka peralatan harus diganti. Jika pergantian peralatan yang jam operasinya telah terpenuhi tidak dilakukan, dikhawatirkan kerusakan yang lebih parah akan terjadi dan menimbulkan kerugian yang lebih besar.

\subsection{Peralatan Kantor}

Menurut Ensiklopedi Administrasi, perlengkapan kantor (office equipment) adalah segenap benda yang dipergunakan untuk membantu kelancaran tugas-tugas tata usaha, yang terdiri dari perabot kantor, mesin kantor, bekal kantor dan hiasan kantor. Sedangkan menurut Kamus Besar Bahasa Indonesia, peralatan kantor berarti sesuatu yang dapat dipakai sebagai alat dalam mencapai maksud dan tujuan. Jadi, dapat dikatakan bahwa peralatan kantor merupakan suatu media dalam upaya mencapai tujuan yang diinginkan.

Secara keseluruhan dapat disimpulkan bahwa yang dimaksud dengan peralatan atau perlengkapan kantor adalah suatu sarana dan prasarana yang dapat memperlancar atau mempercepat pelaksanaan pekerjaan kantor.

Istilah-istilah dalam peralatan kantor adalah sebagai berikut:

- Perabot kantor (office furniture) Yaitu benda-benda yang terbuat dari kayu, besi ataupun bahan lainnya, yang dipergunakan untuk melaksanakan tugas tata usaha dan termasuk perlengkapan kantor tahan lama.

- Mesin kantor (office machines) Yaitu segenap benda yang dipergunakan untuk membantu kelancaran tugas tata usaha seperti mesin-mesin kantor.

- Perbekalan kantor (office supplies) Yaitu benda-benda yang akan habis dalam pemakaian sehari-hari di kantor. Bendabenda tersebut umumnya dipergunakan untuk keperluan tulis-menulis seperti kertas, tinta, pensil, pulpen dan lain-lain.

\subsection{Mesin Kantor}

Mesin kantor merupakan salah satu alat penunjang untuk menyelesaikan suatu pekerjaan dengan efisien. Mesin-mesin kantoradalah sebuah alat yang dipergunakan untuk menghimpun, mencatat dan mengolah bahan-bahan, data ataupun keterangan dalam suatu pekerjaan tata usaha yang cara kerjanya bersifat mekanik, elektrik dan magnetik. Dewasa ini, di kalangan dunia usaha, banyak perusahaan, pemerintahan maupun swasta yang dalam usahanya, semakin mengandalkan mesin kantor guna memungkinkan didapatkan hasil yang optimal.

Perkembangan teknologi yang semakin pesat, menuntut manusia untuk bertindak semakin cepat dengan memperhatikan efisiensi di segala bidang. Menghadapi perkembangan tersebut, tentu saja diperlukan usaha untuk memiliki keterampilan menggunakan mesinmesin kantor akan mendapat keuntungan serta manfaat yang banyak.

Untuk memutuskan perlu atau tidak diadakannya mesin kantor, hendaknya perlu diperhatikan hal-hal berikut:

- Mesin-mesin yang akan dipakai harus benar-benar diperlukan.

- Jenis mesin hendaknya praktis.

- Mesin tersebut dapat mengurangi biaya pelaksanaan pekerjaan.

- Mesin dapat mempercepat selesainya pekerjaan.

- Mutu mesin harus baik.

- Mesin tersebut dapat dipergunakan untuk berbagai macam pekerjaan.

- Pemeliharaan mesin dapat dilakukan dengan mudah. 
- Mesin tersebut dapat disesuaikan dengan kemampuan pegawai.

- Mesin harus sesuai dengan pekerjaan yang akan dilakukan.

- Perlu tersedianya ruangan yang memungkinkan untuk meletakkan mesin tersebut.

- Dipergunakannya mesin dalam suatu proses pekerjaan adalah untuk menghemat secara fisik tenaga dan pikiran manusia dalam melakukan tugas-tugasnya baik yang bersifat rutin maupun yang bersifat insidental, baik untuk pekerjaan-pekerjaan yang bersifat industrial (engineering) maupun yang bersifat teknis catat mencatat atau paperwork. Dan ini tidak lain adalah dalam rangka menyadari arti pentingnya manusia dalam organisasi.

\subsection{Sistem Informasi Pemeliharaan Peralatan dan Mesin Kantor}

Dari definisi di atas, maka penulis dapat menarik kesimpulan bahwa sistem informasi pemeliharaan peralatan dan mesin kantor adalah:

"Sekumpulan komponen dalam mengimplementasikan pencatatan dan perekaman data pemeliharaan peralatan dan mesin kantor sehingga menghasilkan informasi mengenai keadaan peralatan dan mesin kantor, riwayat pemeliharaan dan realisasi anggaran pemeliharaan, yang diperlukan oleh manajemen dalam mengontrol keuangan dan perencanaan anggaran”.

\subsection{Bahasa Pemrograman C\#}

Menurut Griffiths (2012), C\# (dibaca "C Sharp") merupakan sebuah bahasa pemrograman yang digunakan untuk membangun berbagai macam aplikasi seperti aplikasi desktop, website, games dan phone app yang dapat berjalan dalam.NET Framework. C\# programming menyediakan fitur objectoriented dan functional programming. C\# juga menyediakan service seperti runtime type checking, exception handling, danthread management.

Microsoft. NET adalah software yang menghubungkan informasi, orang, sistem dan device. Teknologi inti. NET secara umum terdiri dari 4 area pokok:
1. .NET Framework, menyediakan berbagai library untuk digunakan oleh aplikasi di atasnya. Dot NET Framework adalah lingkungan untuk membangun, menyebarkan, dan menjalankan services Web dan aplikasi lainnya

2. .NET Building Block Services, Building block merupakan sekumpulan services yang bersifat programmable, yang dapat diakses secara offline maupun online. Service tersebut merupakan modul-modul yang terdapat di suatu komputer, server dalam jaringan, maupun di suatu server di internet.

3. Visual Studio. NET, Visual Studio. NET menyediakan tools bagi para developer untuk membangun aplikasi yang berjalan di. Net Framework.

4. Net Enterprise Server, merupakan sekumpulan server based technology yang digunakan untuk mendukung teknologi. NET, yang mencakup sistem operasi, database, messaging, maupun manajemen e-commerce. Teknologi yang disediakan antara lain adalah Windows 2000 Server, SQL Server, Exchange, ISA Server dan BiZTalk Server.

\subsection{Perancangan Sistem}

Perancangan adalah kemampuan untuk membuat beberapa alternatif pemecahan masalah (Al-Bahra, 2005). Pembuatan sistem informasi dibutuhkan adanya perancangan tentang apa yang akan dibuat dan apa yang akan dihasilkan. Adanya suatu rancangan dalam sistem informasi, maka akan mempermudah seorang analisis dalam menentuka kebutuhan sistem.

\subsubsection{Alat Bantu Perancangan Sistem}

\section{a. Data Flow Diagram (DFD)}

Data Flow Diagram merupakan model dari sistem yang menggambarkan pembagian sistem ke modul yang lebih kecil. Salah satu keuntungan menggunakan diagram aliran data adalah memudahkan pemakai atau user yang kurang menguasai bidang komputer untuk mengerti sistem yang akan dikerjakan. (Al-Bahra Bin Ladjamudin, 2013) 
b. Entity Relationship Diagram (ERD)

Menurut Al-Bahra Bin Ladjamudin (2013)Entity Relationship Diagram (ERD) adalah suatu model jarinagan yang menggunakan susunan data yang disimpan dalam sistem informasi secara abstrak. ERD merupakan model jaringan data yang menekankan pada struktur - struktur dan relationship data.

c. Flowchart

Menurut Al-Bahra Bin Ladjamudin (2013), flowchart adalah bagan-bagan yang mempunyai arus yang mengambarkan langkah-langkah penyelesaian suatu masalah. Flowchat merupakan cara penyajian dari suatu algoritma.

\section{ANALISIS DAN RANCANGAN SISTEM}

\subsection{Proses Pemeliharaan}

Proses transaksi dalam pemeliharaan peralatan dan mesin kantor ini mencakup proses usulan perbaikan dan realisasi perbaikan. Proses usulan perbaikan adalah Sub Bagian Umum dan Perlengkapan mencatat usulan perbaikan yang diajukan oleh pemegang peralatan dan mesin. Sedangkan proses realisasi perbaikan adalah proses transaksi yang dilakukan oleh Sub Bagian Umum dan Perlengkapan untuk melakukan pencatatan data realisasi perbaikan melalui faktur yang dikeluarkan oleh Bengkel

\subsection{Context Diagram Sistem Informasi Pemeliharaan Peralatan dan Mesin Kantor}

Context diagram yang menjelaskan pelayanan pemeliharaan peralatan dan mesin kantor sebagai berikut: Bidang mengajukan pemeliharaan, usulan diteruskan ke Bidang Umum an Perlengkapan, diperiksa yang memenuhi syarat dibuat surat pengantar pemeliharaan agar dibaiki dibengkel, bagian Bengkel mengajukan invoice, bagian Bendahara menerima rekap biaya pemeliharaan dari Sistem, Sistem memberikan Kartu Pemeliharaan kepada bagian Bidang, Sistem menyajikan riwayat pemeliharaan, semua aktifitas bisnis dilaporkan ke Kepala Dinas Pendidikan.

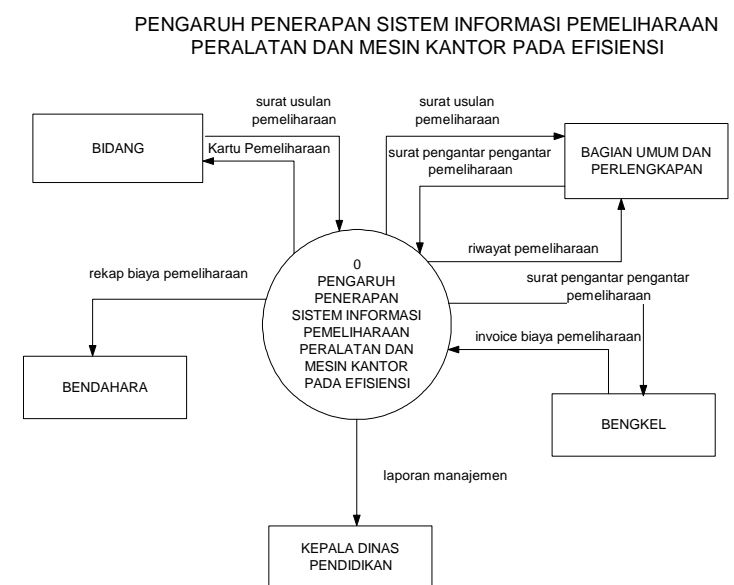

Gambar 3.1. Context Diagram Pemeliharaan Peralatan dan Mesin Kantor

Berdasarkan riwayat pemeliharaan yang ada dapat menjelaskan secara rinci hirtoris pemelihaaraan Peralatan dan Mesin kantor tentang: tanggal kejadian, kerusakan, spare part yang diganti, lama waktu perawatan dan biaya yang ditimbulkan. Selain itu Sistem juga memberikan informasi frekuensi pemeliharaan, kemungkinan overlap pelayanan barang yang sama akan dapat dihindari.

\section{HASIL PENELITIAN}

Pada bagian ini dijelaskan mengenai hasil dari penggunaan aplikasi Sistem Informasi dalam menangani administrasiperekaman data pemeliharaan peralatan dan mesin kantor. Terdapat tiga poin utama yang perlu diuraikan dari hasil penelitian ini yang secara umum dapat membantu manajemen dalam melaksanakan fungsi manajemen di bagian Umum dan Perlengkapan sebagai berikut:

1. Gambar 4.1, 4.4 dan 4.5 menjelaskan riwayat pemeliharaan peralatan dan mesin kantor.Peralatan dan mesin kantor yang masuk kategori perawatan didaftarkan ke Sistem agar dapat dikenali waktu, nama peralatan atau mesin, lama waktu yang terpakai dalam perawatan, bengkel yang melakukan perawatan dan personil yang bertanggung jawab.

2. Gambar 4.2, 4.5dan 4.6merekam biaya perbaikan. Menjelaskan realisasi berbaikan Peralatan dan Mesin Kantor, dari sejumlah barang yang dilakukan 
Penelitian Bidang Komputer Sains dan Pendidikan Informatika

V3.i1(8-17)

pemeliharaan tampak realisasi pencapaiannya. Berdasarkan informasi ini, manajemen dapat menjelaskan biaya yang terpakai, Peralatan dan Mesin yang sering dilakukan perawatan dan menjadikan ini semua menjadi bahan kajian untuk menjelaskan kondisi perawatan hari ini dan yang akan datang. Kondisi yang dapat dijelaskan dari segi biaya, peralatan yang uzur dan biaya yang dikeluarkan per setiap transaksi kegiatan perawatan.

3. Gambar 4.4 dan 4.5 pelacakan informasi yang relevan seperti penyebab masalah. Dari informasi pada gambar tersebut dapat dilacak penyebab terjadinya kerusakan mengacu kepada jenis spare part apa yang sering diganti.

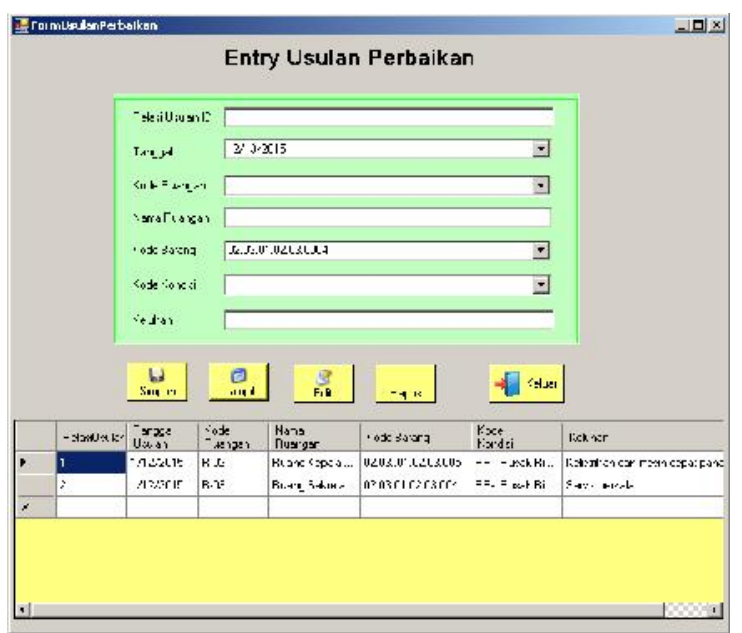

Gambar 4. 1 Usulan Perbaikan Perlatan dan Mesin Kantor

Pada gambar 4.1 Menu Entri Usulan Perbaikan, admin dapat melakukan entri data usulan perbaikan peralatan dan mesin kantor.

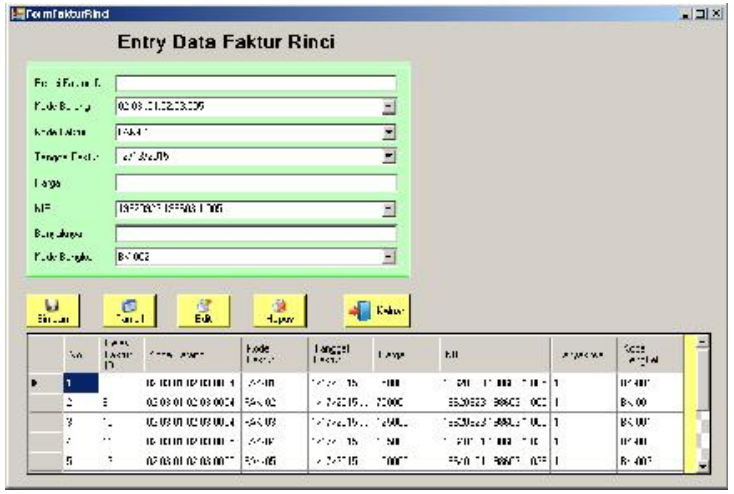

Gambar 4. 2 Realisasi Perbaikan

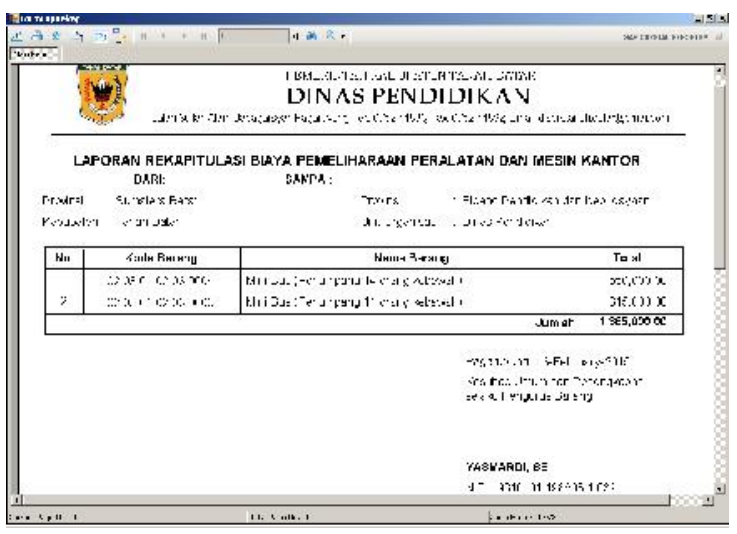

Gambar 4. 3 Rekapitulasi Biaya

Pada gambar 4.3 Laporan Rekapitulasi Biaya merupakan tampilan laporan rekapitulasi biaya pemeliharaan peralatan dan mesin kantor.

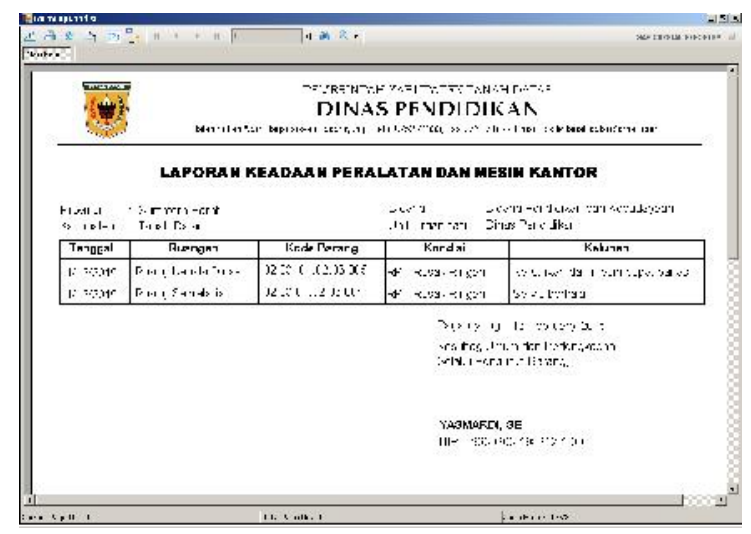

Gambar 4. 4 Laporan Keadaan Peralatan dan Mesin Kantor

Pada gambar 4.4 Laporan Keadaan Peralatan dan Mesin Kantor merupakan 
tampilanLaporan Keadaan Peralatan dan Mesin Kantor.

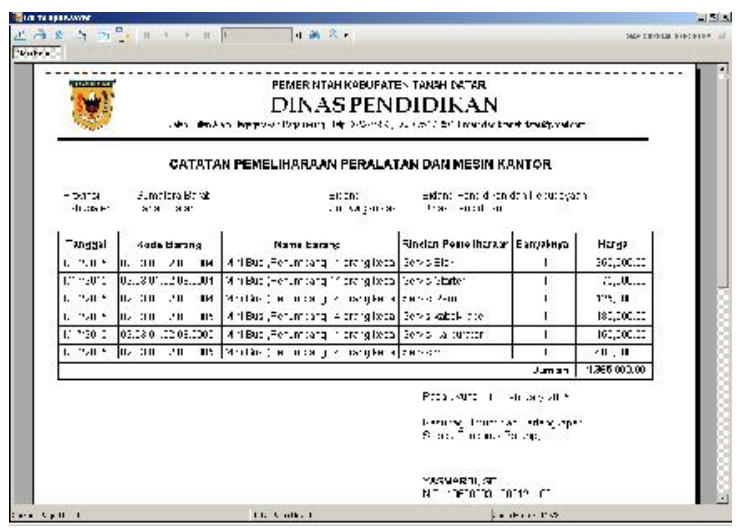

Gambar 4. 5 Riwayat Catatan Pemeliharaan

Pada gambar 4.5Catatan Pemeliharaan merupakan tampilan Catatan Pemeliharaan Peralatan dan Mesin Kantor.

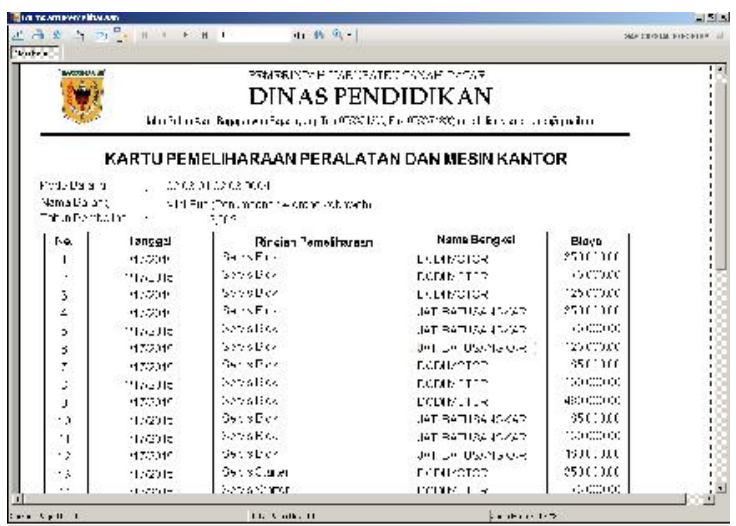

Gambar 4. 6 Kartu Pemeliharaan Peralatan dan Mesin Kantor

Pada gambar 4.6 Kartu Pemeliharaan merupakan tampilan Kartu Pemeliharaan Peralatan dan Mesin Kantor.

\section{KESIMPULAN}

Berdasarkan informasi yang dihasilkan oleh Sistem Informasi dapat membantu manajemen pada bagian Umum dan Perlengkapan yang berkaitan dengan pemeliharaan Peralatan dan Mesin Kantor untuk meningkatkan efisiensi karena Sitem Informasi dapat menyediakan informasi tentang: riwayat pemeliharaan,rekam biaya pemeliharaan danpelacakan informasi yang relevan seperti penyebab masalah. Contoh Efesiensi dari segi biaya tidak lagi dilakukan pemeliharaan terhadap Peralatan yang sudah uzur dan waktu tunggu selama masa perawatan.

\section{SARAN}

Aplikasi Pemeliharaan Peralatan dan Mesin Kantor Dinas Pendidikan Kabupaten Tanah Datar dapat digunakan untuk mendukung optimalisasi kegiatan administrasi pemeliharaan peralatan dan mesin kantor pada Dinas Pendidikan Kabupaten Tanah Datar untuk itu disarankan agar ada pegawai yang terlatih untuk mengoperasikannya.

\section{REFERENSI}

Sudradjat, Ating, 2011. Pedoman Praktis Manajemen Perawatan Mesin Industri. Bandung: PT. Refika Aditama.

Jogiyanto. 2001. Analisis \& Desain Sistem Informasi: pendekatan terstruktur teori dan praktek aplikasi bisnis. Andi, Yogyakarta.

Jogiyanto. 2005. Analisis dan Desain Sistem Informasi. Yogyakarta: Penerbit Andi. Al-Bahra Bin Ladjamudin. 2013. Analisis dan Desain Sistem Informasi. Yogyakarta: Graha ilmu.

Edi purwono. 2002. "Aspek-aspek EDP Audit Pengendalian Internal pada Komputerisasi". Yogyakarta: ANDI.

Andri Kristanto. 2008. Perancangan Sistem Informasi dan Aplikasinya. Graha Media.Yogyakarta.

Edi Purwono. 2006. Apa Yang Harus Diketahui Oleh Sistem Analisis. Andi. Yogyakarta.

Cucu, Ioan., Cucu, Ciprian,. 2009., "Modern Management Methods For Equipment Maintenance", Annales Universitatis Apulensis Series Oeconomica, Vol 11(2), Bucuresti.

Jogiyanto HM. 2009. Sistem Teknologi Informasi, Andi, Yogyakarta.

Rohmat Taufiq. 2012. Sistem Informasi Manajemen. Andi. Yogyakarta.

Tata Sutabri. 2012. Analisis Sistem Informasi. Mediakita. Bandung 
Penelitian Bidang Komputer Sains dan Pendidikan Informatika

Tata Sutabri. 2013. Analisis Sistem Informasi. Andi. Yogyakarta.

Sidik, Betha. MySQL untuk Pengguna, Administrator, dan Pengembangan

Web.Informatika, Bandung. 2005.

Prasetyo, D. D., 2002. Belajar Sendiri Administrasi Database Server My $S Q L$, PT. Elex Media Komputindo Kelompok Gramedia. Jakarta.

Havlík, R. (2011). Multi-criteria scheduling approach for e-maintenance system, Proceedings in Manufacturing Systems, 6(2), 91-96.

Vyskočil, V. (2010). Management podpůrných procesú. Příbram: Professional Publishing 